\title{
Bibliography of Child Study: For the year 1898
}

\section{Louis N. Wilson}

To cite this article: Louis N. Wilson (1899) Bibliography of Child Study: For the year 1898, The Pedagogical Seminary, 6:3, 386-407, DOI: 10.1080/08919402.1899.10532970

To link to this article: http://dx.doi.org/10.1080/08919402.1899.10532970

曲 Published online: 28 Aug 2012.

Submit your article to this journal $\asymp$

Џ Article views: 4

Q View related articles $\sqsubset$ 


\section{BIBLIOGRAPHY OF CHILD STUDY}

For the year 1898 .

By Loots N. Wilson, Librarian, Clark University.

I. Adsersen, H. (On growth in height and mental derangements in childhood.) Nordiskt Med. Arkiv. 1898. Vol. 31, pp. 39.

2. Aicard, Jean L'âme d'un enfant. E. Flammarion, Paris, 1898. pp. 384 .

3. Alden, Annie Fields My Collection of Dolls. Ladies' Home Journal, Nov., 1898. Vol. 15, p. 17; Dec., 1898; Jan., 1899. Vol. 16, pp. 13 and 19.

4. Allport, Frank The eyes and ears of school children. Reprint. The author, 92 State St., Chicago, Ill. pp. 30.

Contains, also, articles on Refraction in Schools: Defective Eyesight in American Children; Tests for Defective Vision in School Children; Physical Defects in Pupils.

5. - Report of eye examinations in the Minneapolis public schools. Jour. of Am. Med. Ass., 1898. Vol. 30, pp. 207-2II.

6. Altenburg, Oskar Die Kunst des psychologischen Beobachtens. Praktische Fragen der pädagogischen Psychologie. Samm1. v. Abh. a. d. Geb. d. Päd. Psy. u Physiol. Band 2, Heft 3,1898 . pp. 76 .

Contains iateresting items concerning the effect of environment, family life, etc., on the child before entering school.

7. Alvarez, B. Gonzales Anatomia y fisiologia especiales del nifo de su alimentacion y crecimiento y preliminares de clinica pediatrica. Carrion Hermanos, Madrid, I895. pp. 344.

A good resume of the anatomy and physiology of childhood, with original contributions. The best book in Spanish on the subject.

8. Aly, Max Voigt Die Welt im Munde. Frankfurt, A. M., I898. pp. 87 .

Practical rules for the care of the teeth and mouth.

9. American, Sadie Child training by the Froebel system. The Woman's Home Companion, N. Y. Sept., I898. Vol. 25, No. 6, p. I2.

Io. - - The movement for small play grounds. Am. Jour. of Sociology, Sept. 1898. Vol. 4, pp. 159-I70.

II. - The movement for vacation schools. Am. Jour. of Sociology, Nov., I898. Vol. 4, pp. 309-325. 
12. Atkinson, Fred. W. A year's study of the entering pupils of the Springfield, Mass., high school. Proc. N. E. A., I8g8. pp. 903-910.

A suggestive application of child study to secondary education.

13. Austin, Ellen M. Child study in the high school. North Western Monthly, March, 1898. Vol. 8, pp. 487-49o.

14. Baginsky, Adolf and Janke, Otto Handbuch der SchulHygiene zum Gebrauche für ärme Sanitätsbeamte, Lehrer, Schul-Vorstände und Techniker. F. Enke, Stuttgart, I898. Vol. I, pp. 748.

15. Bailey, T. P. Child Study and Ethology. North Western Monthly, Nov. 1897; Jan. 1898. Vol. 8, pp. 250-256; 370-375.

16. Baker, Seth Fatigue in school children. Ed. Review, Jan., I898. Vol. 15, pp. 34-39.

A brief statement of some of the premonitions of fatigue.

17. Baldwin, J. Mark The story of the mind. D. Appleton \& Co., N. Y., I898. pp. 236.

The fourth chapter discusses the mind of the child.

I8. Ballet, Thomas M. Value of motor education. Jour. of Education, Nov. 17, 1898. Vol. 48, p. 317.

I9. - School Baths. Jour. of Education Oct. 20, 1898. Vol. 48, pp. 25 I-252.

20. Barnes, Earl Childish ideals. North Western Monthly, Oct., I898. Vo1. 9, pp. 9 I-93.

One of the very few comparisons between the Fnglish and the American child that are of any value.

2x. - The way young children think: a study of their pictures. Child Life (London), June, 1898. Vol. I, pp. I20I22.

Application of recent studies in children's drawings to the Kindergarten.

22. - Effect of social ideas on choice of occupation. Jour. of Education, Sept. 8, 1898 . Vol. 48, pp. 155-156.

A brief study of the ambitions of English school children.

23. - Corporal punishment in England. Education, Oct., I898. Vol. 19, pp. 72-75.

Corporal punishment discussed with special reference to juvenile delinquents.

24. - Corporal punishment as a means of social control. Education, March, 1898. Vol. 18, pp. 387-395.

A study of discipline in English schools.

25. Barr, M. W. The training of mentally deficient children. Pop. Sci. Mo., Aug., 1898. Vol. 53, pp. 531-535.

26. Bastian, H. C. Aphasia and other speech defects. Lewis, London, 1898. pp. 3r4.

27. Baumann, Julius Ueber Willens-und Characterbildung auf physiologisch-psychologischer Grundlage. Samml. von Abh, a. d. geb. d. Paed. Psy. u. Physiol. Vol. I, Hft. I. Renther u. Reichard, Berlin, I897. pp. 86. 
28. Bayr, Emanuel Über Beleuchtungsversuche in Lehrzimmern. Zeit für Schulgesundheitspflege, March, 1898. Vol. II, pp. 129-160.

An exhaustive stndy of the lighting of school rooms.

29. Beach, Fletcher Insanity in children. Jour. of Mental Sci., July, 1898. Vol. 44, pp. 459-473.

30. Beale, Dorothy (and others) Work and play in girls' schools. Longmans, Green \& Co., London. I898. pp. 433.

A comprebensive presentation of the ways and means of educating maturing girls.

3r. Bollianino, C. Troubles de la parole dans 1' hémiplégie infantile. Maloine, Paris, 1898 . pp. 33 .

32. Bergen, F. D. Notes on the theological development of a child. Arena, 1899. Vol. 19, pp. 254-266.

33. Bergey, D. H. School architecture. Heating, ventilation, lighting, and sanitary arrangements. Proc. N. E. A., 18g8. pp. 524-534.

34. Berthelemy, H. La répression des violences commises envers les enfants. Rev. Pédagogique, A pril, x898. Vol. 32, pp. 289-302.

35. Binet, A., et Henri, V. La fatigue intellectuelle. Schleicher Freres, Paris, 1898 . pp. 338 and 3 plates.

An excellent presentation of the physiological and psychological effects of mental overwork; presents the results of many investigations carried on in France, Germany, Italy, and America.

36. Binet, A., and Vaschide, N. La psychologie à l'école primaire. Expériences de force musculaire et de fond chez les jeunes garçons. Épreuves de vitesse chex les jeunes garçons. Expériences sur la respiration et la circulation du sang chez les jeunes garçons. Mesures anatomiques chez 40 jeunes garcons. Échelle des indications données par les différents tests. Corrélation des épreuves physiques. La mesure de la force musculaire chez les jeunes gens. La force de pression de la main, la traction, la corde lisse, le saut. Expériences de vitesse chez les jeunes gens. Données anatomiques, capacité vitale et vitesse du coeur chez 40 jeunes gens. Échelle des indications données par les tests. Corrélation des tests de force physique. Année Psychol., I897. Vol. 4, pp. I-244.

37. Bluhm, R. Die Schulsparkassen in Frankreich. Deuts-Zeits, f. Ausl. Unterr, Jan., 1898. Vol. 3, pp. I15-125.

38. Blum, E. Le mouvement pédologique et pédagogique. Rev. Philos., Nov. 1898. Vol. 46, pp. 504-518.

Review of literature of child study.

39. Boas, Franz The growth of Toronto children. Report Comm. of Ed., 1896-97. Washington, I8g8. Vol. 2, pp. I54II599.

Besides giving the growth of the Toronto children the paper discusses the influence of the order of birth on development. 
40. Bohannon, E. W. The only child in a family. Ped. Sem., April, 1898. Vol. 5, pp. 475-496.

4r. Bolton, T. L., and Haskell, Ellen, M. Knowledge from the standpoint of association. Ed. Review, May, 1898. Vol. 15, pp. 474-499.

42. Bon, L. C. Les chatiments corporels dans les écoles allemandes. Rev. Pédagogique, Jan., I898. Vol. 32, pp. 59-65.

43. Bradford, E. H. (and others) The education of crippled children. American Physical Education Review, September, 1898. Vol. 3, pp. 188-207.

A series of articles on the care and training of deformed and crippled children.

44. Branckmann, K. Behinderte Nasenatmung. Rein's Ency. Handb. d Pädagogik. Vol. 5, pp. 6-12.

45. - Ohrenkrankheiten. Rein's Ency. Handb. d Pädagogik. Vol. 5, Pp. I21-124.

46. Brinton, D. G. The factors of heredity and environment in man. Are. Anthropologist, Sept., 1898. Vol. II, pp. 271-277. Gives an excellent idea of the disagreement of eminent authorities as to the rôle of these factors. Emphasizes the role of character and temperament.

47. Brodeur, Clarence A. Child study in Westfield and vicinity. Jour. of Education, Jan. 6, Jan. 20, Feb. 3 and March 17 , 1898. Vol. 47 .

48. Brower, Daniel R. The judicious training of neurotic children an aid to the prevention of insanity. Proc. of the Am. Med.-Psy. Assn. 54th annual meeting, St. Louis, Mo., May 1o13, I898. Vol. 5, pp. 143-146.

49. Brown, Ernest N. Child study. Educational Record, Province of Quebec, Montreal, March, 1898. Vol. 18, pp. 5I-63. Discusses the subject from the teachers' point of view.

5o. Bruns, L. Hysteria in children. Alienist and Neurologist, July, I898. Vol. I9, pp. 373-430.

5I. Bryant, Sophie The teachings of morality in the family and school. Macmillan Co., N. Y., 1897. pp. 146. Very general.

52. Bucher, M. K. Arbeit und Rhythmus. Allg. Phil. Hist. Classe Sächs. Ges. der Wiss. Bd. 17, No. 5, Leipzig, 1896. pp. I30. "An important and fascinating monograph. Rhythm is born of the "intoxication of work."

53. Buchner, E. F. Reports of child study at state teachers' associations. North Western Monthly, Feb., r8g8. Vol 8, pp. 429-43I.

54. Buck, Winifred Boys' Clubs. N. A. Review, Oct., 1898. Vol. 167, pp. 509-512. 
55. Buisson, F. L'école primaire en France et la part de responsibilité dans l'éducation morale du pays. Rev. Pédagogique, Feb., 1898. Vol. 32, pp. 121-134.

56. Burk, Frederic The graded system $v$ s. individual pupils. North Western Monthly, March, 18g8. Vol. 8, pp. 48I-484.

57. - Growth of children in height and weight. Am. Jour. of Psy., April, 1898. Vol. 9, pp. 253-326.

An excellent summing up of work done in this field. Gives a bibliog raphy of rog titles.

58. —_ Physical measurements. North Western Monthly, May, 1898. Vol. 8, pp. 586-588.

59. - - From Fundamental to accessory in the development of the nervous system and of movements. Ped. Sem., Oct., 1898 . Vol. 6, pp. 5-64.

6o. Burke, Mrs. B. Ellen Children's secrets. Trans. III. Soc. for Child Study, A pril, r898. Vol. 3, pp. 56-6r.

61. Burkhard, P. Die Fehler der Kinder. Nemnich, Karlsruhe, I898. pp. roz.

62. Burnham, Wm. H. Bibliography of school hygiene. Proc. N. E. A. for 1898 . pp. 505-523.

A select list of 436 titles with a few descriptive and critical notes.

63. Burton, Richard Literature for children. N. A. Review, Sept., I898. Vol. 167 , pp. 278-286.

64. Calkins, Mary Whiton Short studies in memory and association. Psychol. Rev., Sept., 1898. Vol. 5, pp. 45I-462.

A study of the immediate and of the delayed recall of the concrete and of the verbal.

65. Camerer, Wilhelm Der Stoffwechsel des Kindes von der Geburt bis zur Beendigung des Wachstums meist nach eigenen Versuchen dargestellt. Zweite Ausgabe mit Ergänzungen. H. Laup'schen Buchhandlung, Tübingen, 1896. pp. I6o. An important study of assimilative and excretive processes.

66. Canton, William W. V. Her book and various verses. Stone \& Kimball, N. Y., 1898. pp. 146.

Records of very 'cute doings and sayings of a child, with the author's poetic elaboration of sone of them.

67. Carlier, Jules Les colonies scolaires et " 1 'œuvre du grand air" de Bruxelles. Rev. Pédagogique, Jan., 1898. Vol. 32, pp. 42-52.

68. Carson, J. C. The importance of a high grade of physical health in feeble-minded inmates of public institutions, with a view to their right development, and the best method of securing such health. Reprint from 3Ist Annual Report, N. Y. State Board of Charities, Jan. 24, I898. pp. ro.

69. Carter, Marion H. Darwin's idea of mental developement. Am. Jour. of Psy., July, r898. Vol. 9. pp. 534-559. 
70. - Educational paper dolls. Jour. of Pedagogy, April, 1898. Vol. II, pp. I33-I44.

An excellent exposition of the use to be made of paper dolls in the study of myths, history, and literature.

71. Chamberlain, Alex. F. The lesson of "the little child." North Western Monthly, Feb., x898. Vol. 8, pp. 435-439.

72. Chase, Susan F. Choice of reading for the early adolescent years. Proc. N. E. A., 1898. pp. IoII-ror5.

73. Chrisman, Oscar The secret language of children. North Western Monthly, Jan. and June, r898. Vol. 8, pp. 375-379; $949-651$.

74. - Results of child study. Education, February, I 898 .

Vol. 18, pp. 322-332.

Based on replies to a questionnaire sent to teachers.

75. _- Religious ideas of a child. Child Study Mo., March, 1898. Vol. 3, pp. 516-528.

76. - Paidology, the science of the child. Ed. Rev., March, 1898. Vol. 15, pp. 269-285.

A summery of the authot's dissertation submitted to the University of Jena for the degree of Doctor of Philosophy.

77. - The secret language of childhood. Century, May, I898. Vo1. 56, pp. 54-58.

78. - - Religious periods of child-growth. Ed. Rev., June, I898. Vol. I5, pp. 40-48.

79. — Child and parent. North Western Monthly, Nov., Dec., I898. Vol. 9, pp. 135-138; 180-r83.

80. Clapp, Henry L. School gardens. Pop. Sci. Mo., Feb., I8g8. Vol. 52, pp. 445-456.

81. Coe, George A. The morbid conscience of adolescents. Trans. Ill. Soc. for Child Study, Oct., 1898. Vol. 3, pp. 97-I08.

82. Cohn, Hermann Die Schulartz frage in Breslau. Zeit. flir Schulgesundheitspflege, Nov. I8g8. Vol. $x$ I, pp. 579-596.

83. Colling, Joseph The genesis and dissolution of the faculty of speech: a clinical and psychological stndy of aphasia. Macmillan Co., N. Y., I898. pp. 432.

The most valuable treatment of speech disturbances to be found in the English language.

84. Collins, Patti Lyle What children ask of Santa Claus. Ladies' Home Journal, Dec., 1898. Vol, 16, p. 31.

85. Colozza, G. A. Del potere dell'inibizione; nota di pedagogia. Paraira, Roma, I898. pp. 128.

A good study of inhibition.

86. Compayré, Gabriel Saturday teachers' class at the Westfield normal school. Education, Feb., 1898. Vol. I8, pp. 26I264.

The translation of an article published in Manuel Géneral de l'Instruction Primaire (Paris), for Oct. 16,1897 . 
87. Core, E. B. Getting good pictures of children. Ladies' Home Journal, Feb., 1898. Vol. 15, No. 3, p. 13.

88. Curtis, Henry S. Inhibition. Ped. Sem., Oct. I898. Vol. 6, pp. $65-113$.

89. Curtis, H. S., and Partridge, G. E. Child study in connection with the vacation achools. Report on the vacation schools and playgrounds, N. Y. City. Borough of Manhattan and the Bronx, I898. pp. 51-97.

9o. Curtiss, Frank Homer, Some investigations regarding loss in weight and gain in height during sleep. Am. Phys. Ed. Rev., December, 1898. Vol. 3, pp. 270-273.

91. Darrah, Estelle M. A study of children's ideals. Pop. Sci. Mo., May, I898. Vol. 53, pp. 88-98.

An excellent statistical study of children's estimate of character.

92. Dawson, Geo. E. Child study. A series of articles in the International Evangel, Sept., I897 to Sept., I898.

93. Defert, Louis L'enfant et l'adolescent dans la société moderne. Préface de M. Th. Roussel. Montgrédien et Cie, Librairie Illustrée, Paris, I898. pp. 221 .

A popular work, devoted chiefly to infancy. Author maintains absointe neutrality, seeks only to present facts.

94. Delabarre, E. B. A method of recording eye movements. Am. Jour. of Psy., July, r898. Vol. 9, pp. 572-574.

95. Delpench, A. La période prépubére. Presse Méd, Paris, I898. Vol. 2, pp. 89-94.

96. Delvaille, C. L'hygiène scolaire au congrès international d'hygiène de Madrid. Rev. Pédagogique, Aug., 18g8. Vol. 33, pp. II5-126.

97. Demolins, Edmond Anglo-Saxon superiority: to what it is due. R. F. Fenno \& Co., N. Y., r8g8. pp. 343.

In part I, asks whether the French, German and English school system forms men. and how to bring up our children.

98. Deucker, R. Das Kind und diegeschlechdiche Entwickelung. Spohr, Leipzig, I8g8. pp. 36.

99. Dewey, John Some remarks upon the psychology of number. Ped. Sem., Jan., 1898. Vol. 5, pp. 426-434.

Ioo. Dexter, Edwin G. The child and the weather. Ped. Sem., April, I898. Vol. 5, pp. 512-522.

See, a1so, North Western Monthly, Oct., r8g8. Vol. 9, pp. 93-97.

IoI. Dieckhoff, Chr. Die Psychosen bei psychopathisch-minderwertigen. Allg. Zeits. f. Psychiat., 1898. Vol. 55, pp. 215-250.

102. Dinsmore, J. W. Running away. North Western Monthly, Dec., I898." Vol. 9, pp. $183-186$.

103. Dodd, C. A study in school children. National Rev., 1898. Vol. 32, pp. 66-74. 
104. Donath, Julius Die Anfänge des menschlichen Geistes. Fest-Vortrag, gehalten in der Jahresversammlung der Gesellschaft der Budapester Hospitalsärzte, am 29. Dezember, 1897. Stuttgart, F. Enke, $1898.47 \mathrm{s.}$

A very interesting discussion of the mind of the child in relation to the savage and the race.

I05. Du Bois, Patterson The Sunday school as a force. North Western Monthly, Feb., 1898. Vol. 8, pp. 439-442.

106. Eulott, Delia M. Use of the voice in teaching. Am. Phys. Ed. Rev., Sept., 1898. Vol. 3, pp. 216-219.

107. Ellis, A. Caswell Play in educetion. Nortt Western Monthly, Nov., I8g8. Vol. 9, pp. I40-143.

ro8. Ellis, Havelock Auto-erotism: A psychological study. Alienist and Neurologist, April, 1898. Vol. 19, pp. 260-299.

A thorough general study of some sex-phenomena.

rog. Fxdmann, Benno und Dodge, Raymond Psychologischen Untersuchungen aber das Lesen auf experimenteller Grandlage. Niemeyer, Halle A. S., 1898 . pp. 360 .

Considers rest and motion of the eye in reading. Gives descriptions of apparatus.

IIo. Evellin, F. Rapport sur l'enseignement de la morale dans les écoles primairea de l'academie de Paris. Rev. Pédagogique, Feb., 1898. Vol. 32, pp. 97-120.

II1. Fall, Delos School diseases and medical inspection. Proc. N. E. A., 1898. pp. 534-544.

I12. Fauth, Franz Das Gedächtnis, Samml. von Abh. a. d. geb. d. Paed. Psy. u. Physiol. Band I, Heft 5. Reuter \& Reichard, Berlin, 1898. pp. 88.

Ir3. Felker, Allie M. Play as a means of ideallzing and extending the child's experience. Proc. N. E. A., 1898. pp. 624-632.

114. Féré, Ch. La famille neuropathique. 2d ed. F. Alcan, Paris, 1898.

Valuable as a guide to the literature of the oubject. Large list of authors cited.

115. Ferrar, G. C. Manifestazioni artiatiche accessuate in una bambina. Archiv. di Psichiat., 1898. Vol. 19, pp. 238-256.

116. Fitz, Geo. W. The hygiene of instruction in primary schools. Proc. N. E. A., r898. pp. 544-550. AlBo, in Am. Physical Ed. Rev., Dec., I898. Vol. 3, pp. 242-248.

A strong plea for the correlation of mental and physical development.

117. Fletcher, Horace That lost waif or social quarantine, Chicago: Rindergarten Literature Co., 1898. pp. 270.

A otudy of neglected and abandoned children.

118. Frend, 8. Die infantile Cerebrallähmung. Hölder, Vienna, 1897. pp. 327. 
I19. Galbreath, Louis $H$. The study of children by teachers. North Western Monthly, Apri1, 1898. Vol. 8, pp. 54I-544.

120. - Child study for class work. Trans. I11. Soc. for Child Study, April, 1898. Vol. 3, pp. 18-28.

121. - Child study in the art of teaching. Journal of Pedagogy, July, 1898. Vol. II, pp. 237-252.

Discusses some of the more direct pedagogic bearings of child study.

I22. - - Practical course in child study for teachers. Trans.

I11. Soc. for Child Study, Oct., 1898. Vol. 3, pp. 153-170.

123. Gallaudet, E. M. The deaf and their possibilities. Proc. N. E. A., 1898 . pp. 207-214.

I24. Gates, Fanny B. Musical interests of children. Journal of Pedagogy, October, I898. Vol. I I, pp. 265-284.

A statistical study of the eong preferences of 2000 school children with the reasons for preferences; also, discusses briefly the music sense among primitive people.

125. Gattel, F. Ueber die sexuellen Ursachen der Neurastheni u. Angstneurose, Hirschwald, Berlin, 1898 . pp. 68.

126. Gélineau, - Hygiène de l'oreille et des sourds. Maloine, Paris, 1897. pp. 127.

127. Gilles, L. Du calcul de la mortalité des enfants placés en nourtice. Gy. Ronen, r898. pp. 20.

Gonzales-Alvarez, B. See Alvarez, B. Gonzales

128. Gordy, J. P. What can child study contribute to the science of education? Proc. N. E. A., I898. pp. 348-354.

I29. Götze, C. Das Kind als Künstler, Hamburg. Lehrervereinigung für die Pflege der künstlichen Bildung, r8g8. pp. $3^{6}$ and 8 plates.

Summarizes the results of inductive studies on children's drawings.

130. Gould, George M. Child fetiches. Ped. Sem., Jan., I 898. Voi. 5, pp. 42I-425.

13I. Griffth, E. W. Interest from the child study point of view. Child Study Monthly, Nov. 18g8. Vol. 4, pp. 285-287.

132. Groos, Karl The play of animals (Trons. by Elizabeth L. Baldwin). D. Appleton \& Co., N. Y., 1898. pp. $34 \mathrm{I}$.

Although dealing primarily with the play instinct in animals there is much in the book bearing on the plays of children.

133. - - Uber die Necklust. Die Kinderfehler, March, 1898 .

Vol. 3, pp. 33-39.

An account of the teasing and bullying instincts of children.

134. Groszmann, M. P. E. Language teaching from a child study point of view. Child Study Monthly, Nov., I898. Vol. 4, pp. 266-278.

135. Gulick, Luther The religion of boys. The Asssociation Outlook, Springfield, Mass. Vol. 8, pp. 33-48. 
136. - Sex and religion. Series of articles published during 1897-98, in Association Outlook, Springfield, Mass.

137. - - Some psychical aspects of muscrlar exercise. Pop. Sci. Mo., Oct., I898. Vol. 53, pp. 793-805.

An admirable statement of the psychological basis of play.

138. Gutzmann, H. Das Stottern. Rosenheim, Frankfort a. M., I898. pp. 467.

I39. Faddon, Alfred C. The study of man. G. P. Putnam's Sons, N. Y., 1898 . pp. 4 ro.

Contains chapters on measurements and their importance in anthropometry, toys and games, and the singing, counting and funeral games.

I40. V. Hagen, Karl Die Geschlechts-Bestimmung des werdenden Menschen und was wir über die geschlechtliche Vorausbestimmung wussten und wissen. H. Steinitz, Berlin, 1898. pp. 60.

14I. Hall, G. Stanley Some aspects of the early sense of self. Am. Jour. of Psy., April, 1898. Vol. 9, pp. 321-395.

142. - New phases of child study. Child Study Monthly, May, I898. Vol. 4, Pp. 35-40.

A brief statement of some characteristics of adolesence.

143. - - Initiations into adolescence. Proc. Am. Antiq. Soc., Worcester, Mass., Oct. 21, 1898. Vol. 12, pp. 367-400.

144. - - The love and study of nature: a part of education. Agriculture of Mass., I898. pp. I34-154.

Lectures delivered before the Mass. State Board of Agriculture at Amherst, Dec. 6, I898. Treats of child's attitude toward nature.

145. - - Topical Syllabi, 1898-99. I. The organizations of American Student Life with Henry D. Sheldon; II. Mathematics in Common Schools, with E. B. Bryan; III. Mathematics in the Early Years, with E. B. Bryan; IV. Unselfishness in children, with willard S. Small; V. The Fooling Impulse in Man and Animals, with Norman Triplett; VI. Confession, with Erwin W. Runkle; VII. Pity ; VIII. Perception of Rhythm by Children, with Chas. H. Sears.

146. Hall, Jeanette W. The period of adolescence. Child Study Monthly, June, 1898. Vol. 4, pp. 68-82.

Contains a bibliography of 21 titles but most of the references are incomplete.

147. Halleck, Reuben Post Some contributions of child study to the science of education. Proc. N. F. A., r898. pp. 254-262.

148. - The education of the motor centers. Trans. I11. Soc. for Child Study, April, 1898. Vol. 3, pp. 46-55.

I49. Hancock, John A. Children's tendencies in the use of written language forms. North Western Monthly, June, I8g8. Vol. 8, pp. 646-649. 
I50. Haney, James $P$. The hundredth child. Reprint from the Teachers' Quarterly, N. Y. City, I8g8. pp. I3.

I5I. Harris, William T. (and others) The psychology of the initiative functions in childhood as related to the process of learning. Rep. Comm. of Ed. for $1896-97$. Vol. $x$, pp. 676-68r.

152. - Effect of exercise on the vital organs. Proc. N. E. A., r898. pp. 930-933.

153. Hartwell, Edward M. School hygiene-what it is and why we need it. Proc. N. E. A., r898. pp. 498-505.

Haskell, Ellen M. See Bolton and Haskell (No. 4I).

r54. Henie, C. Untersuchungen über die Zähne der Völksschuler zu Hamar in Norwegen. Zeit. für Schulgesundheitspflege, Feb. 1898. Vol. II, pp. 65-7I.

A careful investigation of the condition of the teeth of the school children in a Norwegian town of 5000 inhabitants.

155. Henri, Victor and Catherine Earliest recollections. Pop. Sci. Mo., May, 18g8. Vol. 53, pp. I08-I15.

Reminiscent study of childhood.

156. Hogan, Loulse A. A study of a child. Harper \& Bro., N. Y., 1898. pp. 220.

A rather diffuse history of a child during the first seven years of its life. Iliustrated.

157. Holmes, Manfred J. Apperception and child study. Trans. I11. Soc. for Child Study, Oct., 1898. Vol. 3, pp. 145-r52.

I58. Hrdulcka, Ales Report on anthropological work in the state institution for feeble-minded children, Syracuse, N. Y. Supplemental to 48 th Annual Report, 1898. pp. 98.

159. - - Anthropological investigations on 1000 white and colored children of both sexes. $47_{\text {th }}$ Annual Report, N. Y. Juvenile Asylum. State Printers, N. Y. and Albany, 1899. Pp. 86.

An excellent piece of work. Commendable for its conservative tone.

160. - The medico-legal aspect of the case of Maria Barbella. State Hospitals' Bulletin, Utica, N. Y., April, 1897. pp. I-87, with 2 charts and rg figures.

16r. Huey, Edmund $B$. Preliminary experiments in the physiology and psychology of reading. Am. Jour. of Psy., July, 1898. Vol. 9, pp. 575-586.

r62. Hugh, D. D. Formal education from the stand point of physiological psychology. Ped Sem., April, I898. Vol 5, pp. 599605 .

163. Itard, - Rapports et mémoires sur le sauvage de 1' Aveyron, l'idiotie et la surdi-mutité. Avec une appréciation de ces rapports par Delasiauve. Préface par Bourneville. Eloge d'Itard par Bousquet. Félix Alcan, Paris, 1894. pp. 144.

A reprint, with notes and introduction, of a classic. 
164. Ireland, William $\mathbf{W}$. The mental affections of children, idiocy, imbecility, and insanity. J. \& A. Churchi11, London, 1898. pp. 442.

An authoritative work on the care and training of mentally deficient childrea.

165. Jacobi, Mary Putnam Care of the adolescent girl. The Mother's Voice, Jan., 1898. Vol. 2, pp. 2-3; I3-15.

166. Jegi, John I. Children's ambitions. Trans. I1l. Soc. for Child Study, Oct., 1898. Vol. 3, pp. I3I-I44.

Treats of German children in Milwaukee. Conservative in general tone, and valuable.

167. Johnson, George E. Play in physical education. Proc. N. E. A., 1898 . pp. $948-958$.

168. Juvenile Offenders. A report based on an inquiry institated by the committee of the Howard Association. Wertheimer, Lea \& Co., London, 1898 . pp. 39 .

The opintons are almost universally opposed to imprisonment and in favor of whipping.

169. Kemsies, Ferdinand Arbeitshygiene der Schule auf Grund von Ermüdungsmessungen. Samml. v. Abh. a. d. Geb. d. Päd. Psy. u. Physiol. Band 2, Heft I, 1898. pp. 64.

A study of the effect of fatigue on the quality and quantity of matnematical work made by means of the ergograph.

17o. Keyes, Chas. H. What can child study do for our schools ? North Western Monthly, June, I898. Vol. 8, pp. 641-644.

Abstract of an address before meeting of the Conn. Teachers' Ass'n, Willimantic, Conn., May 6 , 1898 .

171. Kiernan, James G. The periods of stress in childhood. Trans. I1l. Soc. for Child Study, Oct., 1898. Vol. 3, pp. $91-96$.

I72. Kirkpatrick, E. A. The problem of children's reading. North Western Monthly, June, r898. Vol. 8, pp. 65I-654.

I73. —— Children's reading I. North Western Monthly, Dec., 1898. Vol. 9, pp. I88-IgI.

174. - Defects in the eyes of children. State Normal School, Fitchburg, Mass., I8g8. pp. 7.

A little pamphlet sent out to parents of children whose eyes are found defective.

I75. Kittredge, F. E. Adenoids and their complications in children. N. Y. Med. Jour., Nov. 12, 1898. Vol. 68, pp. 702-706.

176. Kline, Linus $W$. Truancy as related to the migratiog instinct. Ped. Sem., Jan., 1898. Vol. 5, pp. 381-420.

177. — - The migratory impulse vs. love of home. Am. Jour. of Psy., Oct., 1898. Vol. I0, pp. I-8I.

178. Knapp, Ludwig Der Scheintod der Neugeborenen. Braumiuller, Wien u. Leipzig, 1898 . pp. 163.

Largely on the development of the yarious methods of seanimating apparently dead new boru children, Bibliography of $13 \mathrm{pp}$. 
I79. Kohlbrugge, I. H. F. Der Atavismus. Scrineriüs, Utrecht, r897. pp. $3^{x}$.

I80. Krauss, W. C. The stigmata of degeneration. Am. Jour. of Insanity, July, r898. Vol. 55 , pp. 55-88.

181. Kraus-Boelté, Maria The development of the inner life of the child. Proc. N. E. A., 1898. pp. 608-6r4.

182. Krohn, William $O$. Minor mental abnormalities in children as occasioned by certain erroneous school methods. Child Study Monthly, Oct., I898. Vol. 4, pp. 20I-2I4.

183. Kuhn, Maurice Les enfants degénérés dans les écoles publiques. Rev. Pédagogique, Jan., 1898. Vol. 32, pp. 53-58. Translation and discussion of a paper on feeble-minded children in the public schools, by will s. Monroe.

184. Laing, Mary E. An inductive study of interest. Ed. Review, Nov., 1898. Vol. I6, pp. 38I-390.

185. Lancaster, E. G. The vanishing character of adorescent experiences. North Western Monthly, June, I898. Vol. 8, pp. $644-646$.

186. Lang, Ussian H. Some cautions to be observed in child study. Proc. N. E. A., I898. pp. 898-902.

187. Law, Frederick H. Age at which children leave school. Ed. Rev., Jan., 1898. Vol. I5, pp. 40-49. Discusses the extent of school training of children in $N$. Y. City.

I88. Lay, W. A. Führer durch den Rechtschreibunterricht. Nemnich, Karlsruhe, r897. pp. 230. Contains an account of important investigations in regard to spelling.

I89. Lay, Wilfred Mental imagery. Experimentally and subjectively considered. The Psychol. Review Monograph Supp. Vol. 2, No. 3, May, 1898. pp. 59.

Igo. Leclère, A. Description d'un objet. L'Anné Psychol., I897. Vo1. 4, pp. 379-389.

19I. Lemox, D., and Sturrock, A. The elements of physical education. A teacher's manual. Wm. Blackwood \& Sons, Londor, 1898. pp. 24 I.

A practical and interesting book.

192. Letchworth, Wm. Pryor Dependent children and family homes. The Sanitarian, N. Y., Jan., 1898. Vol. 40, pp. 3-14.

193. Lietz, Hermann Emlohstobba. Berlin, 1897. pp. 192.

194. Loeper, F. Ueber Organisation von Hilfsschulen. Die Kinderfehler, Nov., I898. Vol. 3, pp. I67-r77.

A discussion of the question of separate classes for the mentally dull.

195. Lombroso, Paolo (The logical consistency of the ideas of children) Voprosi Philos. Moscow, Jan., Feb.; Mch., Apr., I898. Year 9, pp. 23-40; 99-1 Io. 
Luckey, G. W. A. (See Child Study Department, North Western Monthly, I898. Lincoln, Neb.)

196. Iui, Aurelio L'isterismo infantile. Riv. Sper. di Freniat, 1898. Vol. 24, pp. 745-771.

Resume of recent studies on hysteria in children.

197. Lukens, Herman $T$. The school fatigue question in Germany. Ed. Review, March, 1898. Vol. 15, pp. 246-254.

An excellent statement of recent investigations in Germany and especially of the labors of Kraepelin and Griesbach.

198. - The method of suggestion in the cure of faults. North Western Monthly, May, 1898. pp. 592-595.

199. — - Notes abroad. Ped. Sem., Oct., 1898. Vol. 6, pp. 114-125.

200. Mackenzie, John Noland The physiological and pathological relations between the nose and the sexual apparatus of man. Bull. of the Johns Hopkins Hospital, Jan., r898. Vol. 9. pp. 10-17.

20I. McKenzie, R. Tait Influence of school life on curvature of the spine. Proc. N. E. A., I898. pp. 939-948.

202. MeLeish, Mrs. Andrew Observations in the development of a child in the first year. Trans. Ill. Soc. for Child Study, Oct., 18g8. Vol. 3, pp. Iog-124.

A rather careful bit of individual child study made by an obsetving mother.

203. MacLennan, S. F. Method in child study, with special reference to the psychological point of view. Trans. Ill. Soc. for Child Study, April, 1898. Vol. 3, pp. 29-45.

204. MeMurry, Lida Brown Relation between parents and teachers. School and Home Education, Sept., 1898. Vol. 18, pp. 17-18.

205. Mall, Franklin P. Development of the human intestine and its position in the adult. Bull. of the Johns Hopkins Hospital, Sept., Oct., 1898. Vol. 9, pp. 197-208.

First attempt to trace the position and growth of the intestine from the embryo to the adult.

206. Mansfield, Edith Conflict of authority. Child Study Monthly, March, 1898. Vol. 3, pp. 529-539.

A good statistical study of school discipline from the child's standpoint.

207. Marina, Giuseppe Ricerche antropologiche ed etnografiche sui ragazzi. Bocra, Torino, 1896. pp. 86.

Anthropometric studies of Italian boys. Has a good bibliography.

2c8. —— Studi antropologici sugli adulti. Bocca, Torino, 1897. pp. 38.

Companion Vol. to preceding.

209. Marshall, Henry R. Instinct and reason. The Macmillan Co., N. Y., I8g8. pp. 574 . 
2ro. Mead, George H. The child and his environment. Trans. Ill. Soc. for Child Study, April, I898. Vol. 3, pp. I-II.

2rr. Merrill, Jennie B. Children's gardens. North Western Monthly, Oct., 1898. Vol. 9, pp. 89-90. Also, Proc. N. E. A., I898. pp. 598-602.

212. Milliken, O. J. Chicago vacation schools. Am. Jour. of Sociology, Nov., 1898. Vol. 4, pp. 289-308.

2I3. Mills, Wesley The nature and development of animal intelligence. The Macmillan Co., N. Y., r898. pp. 307.

A valuable addition to the literature of the subject. Well indexed.

214. Moll, A. Das nervöse Weib. F. Fontane et Cie., Berlin. pp. 226.

215. Möller, P. Ueber Intelligenzprüfungen. Ein Beitrag zur Diagnostik des Schwachsinus. Berlin, 1897. pp. 32.

216. Monroe, Will S. Vocational interests of children. Education, Jan., 18g8. Vol. 18, pp. 259-264.

A statistical study of the ambitions of 1,755 elementary school children.

217. - - Über die Behandlung der Verbrecher. Die Kinderfehler, Jan., 1898. Vo1. 3, pp. 19-22.

Describes the training of adolescent delinquents in America.

218. - Chorea among public school children. American Physical Education Review, March, 1898. Vol. 3, pp. 19-24.

Translated into German by Jobann Trüper and published in Die Kinderfehler, Sept., 1898. Vol. 3, pp. 155-160.

219. — Das Studium der Kindesseele in Amerika. Deutsche Zeit. für Ausländisches Unterrichtswesen, April, 1898. Vol. 3, pp. 193-203.

Historical and descriptive account of the child study movement in America.

220. - Development of the social cousciousness of children. North Western Monthly, Sept., I898. Vo1. 9, pp. 3I-36. A1so Proc. N. E. A., I898. pp. $92 \mathrm{I}-928$.

Traces briefly the genesis of the social sense in animals, primitive man, and the child.

221. - Child study outlines. Second series: I. Children's spontaneous drawings. 2. The money sense of children. 3 . Memory types of children. 4. Perception of children. 5. Fatigue in school children. 6. Growth of children. 7. Psychology of adolescence. 8. Imitation in childhood. 9. Suggestibility of children. Wright \& Potter Printing Co., Boston, 1898 .

A series of nine outlines suggesting specific studies, hlnts for the collation of the material collected, and bibliographic references to the literature of the subject.

See, also, No. 183 .

222. Morton, Aima B. Child study and education. Public School Journal, Feb., I898. Vol. 17, pp. 289-293. 
223. Mott, T. A. Contagious diseases in school. Proc. N. E. A., 1898. pp. $3^{81-386}$.

Muffang, H. See Ammon $O$.

224. Munro, Mary F. Three years in the life of a child. Ed. Review, Nov., 1898. Vol. 16, pp. 367-377.

225. Mutke, Robert Die Behandlung stammelnder und stotternder Schüler. Breslau, I898. pp. 30.

Relates largely to the pedagogic and didactic treatment of stammerets who relapse. Author is director of the curative course of the Breslau Institution for stammering children.

226. Neuman, B. P. Take care of the boys. Fortnightly Rev., Sept., 1898. Vol. 70, pp. 4ro-42I. Also Living Age, Nov. 19, 1898. Vol. 219, pp. 503-513.

227. Nolkov, D. Das Aktivitätsprincip in der Pädagogik J. J. Rousseau's. Schmidt, Leipzig, 1898 . pp. 160.

228. Noss, Theo. B. Child study record. The Author, Southwestern State Normal School, California, $\mathrm{Pa}$.

A convenient individual record book prepared for the author's classes in pedagogy.

229. Oltuszevski, W. Die geistige und sprachliche Entwickelung des Kindes. H. Cornfeld, Berlin, I897. pp. 43 .

Gives monthly details of linguistic development of a Polish child, Valuable for comparison with Preyer, whose work the author bas carefully collated with his own.

230. Oppenheim, Nathan The derelopment of the child. Macmillan Co., N. Y., 1898. pp. 296.

Contents: Facts in the comparative development of the child; importance of heredity and environment; the primary school; religion; the child as a witness in suits of law; the child-criminal; the genius and the defective; the child and institutional life; the profession of maternity.

23I. Osborn, F. W. Wordsworth's poems of children and childhood. Fiducation, Oct., I898. Vol. 18, pp. 93-99.

A brief study of the child in literature.

232. O'Shea, M. V. "Spare the rod and spoil the child." The Outlook, Jan. 8, 1898. Vol. 58, pp. I28-130.

Results of child study applied to corporal punishment.

233. — The purpose, scope and method of child study. Jour. of Pedagogy, Jan., I898. Vol. I I, pp. 9-23.

A forceful statement of the practical utility of child study.

234. - - Some adolescent reminiscences. Jour. of Pedagogy, Oct., 1898. Vol. 1x, pp. 299-3I7.

A study based on replies to a questionnaire from forty college students on their recollections as to growth, intellectual and emotional phenomena, dress, etc., during early adoleseuce.

235. Oswald, Felix L. The secret of atavism. Pop. Sci. Mo., June, 1898. Vol. 53, pp. 192-I96.

236. Partridge, George E. Reverie. Ped. Sem., April, 1898. Vol. 5, pp. 445-474.

See, also, No. 89 . 
237. Pearson, Karl On a scale of intelligence in children. Jour. of Ed., London, Sep., I898. N. S. Vol. 20, pp. 509-510.

238. Peck, E. A. Defective vision. Child Study Monthly, June, I898. Vol. 4, pp. 100-I04.

239. Pelopi, - De la precocité et des perversions de l'instinct sexuel chez les enfants. Bordeau, 1898.

240. Petit, Edouard Autour de 1'école du soir: I. Chez les adolescents; II. Chez les ouvriers; III. Chez les soldats. Revue Pédagogique, April, I8g8. Vol. 32, pp. 303-322.

241. - Ames d'écoliers. Rev, Pédagogique, Nov, 1898. Vol. 33, pp. $377-387$.

242. Phelps, G. M. Care of children's teeth. Child Study Monthly, Oct., 1898. Vol. 4, pp. 225-233.

243. Pierce, A. H. The illusion of the Kindergarten pattern. Psychological Review, May, 1898. Vol. 5, pp. 233-253.

244. Pierce, John M. Psychological aspects of physical education. Am. Phys. Ed. Review, March, 1898. Vol. 3, pp. 30-37.

245. Phillips, Daniel E. Some remarks on number and its application. Ped. Sem., April, 1898. Vol. 5, pp. 590-598.

246. Plummer, Edward $M$. The Olympic games in ancient times. Am. Phys. Ed. Review, March and June, 1898. Vol. 3, pp. I-r8; 93-106.

247. — - Toys and games for children among the ancient Hellenes. Am. Phys. Ed. Review, Sept., 1898. Vol. 3, pp. 157-I69.

248. Pollock, Susan P. Ideal play in the Kindergarten. Proc. N. E. A., 1898. pp. 604-608.

249. Porter, Isaac, Jr. Photographing children at home. Ladies' Home Journal, Dec., I898. Vol. 16, No. I, p. 35 .

250. Powell, W. B. Medical inspection of schools. Proc. N. E. A., 1898. pp. 454-462.

25r. Quantz, J. O. Dendro-psychoses. Am. Jour. of Psy., July, I898. Vol. 9, pp. 449-506.

252. Quincy, Josiah Playgrounds, baths, and gymnasia. Am. Phys. Ed. Review, Dec., 1898. Vol. 3, pp. 234-241.

253. Ragonin, Zenaide A. Tales of the heroic age; Siegfried \& Boewulf. G. P. Putnam's Sons, N. Y., 1898. pp. 332.

Addressed to childbood under the conviction that myth is essential. Timely and valuable for every teacher of literature.

254. Regnault, $\mathbf{F}$. et Raoul Comment on marche. Lavanzelle, Paris, I898. pp. I88.

255. Report of the Chicago Vacation School Committee of Women's Clubs, Chicago, 1898. pp. 44. 
256. Report of the Departmental Committee on Defective and Epileptic Children. Vol. I. The Report, pp. 42; Vol. 2. Minutes of Evidence, Appendices, etc., pp. $28_{3}$. Eyre \& Spottiswood, London, 1898 .

Recommends that teachers be trained to make special observations upon these children.

257. Robinson, Harriet H. Loom and spindle, or life among the early mill girls. T. Y. Crowell \& Co., N. Y., I898. pp. 216.

Valuable for its details and economic history.

258. Rohleder, H. Die Masturbation. Fischer's Med., Buchbandig, Berlin, I898. pp. 3rg.

A monograph for physicians and teachers. Elaborate and systematic.

259. Rosenfeld, Leonhard Arbeitsschulen für Verkrüppelte. Zeit. für Schulgesundheitsptlege, Jan., I898. Vol. II, pp. 4-18. An account of the European movement to give special training to crippled and deformed children.

260. Roubinovitch, Dr. L'alcool, l'enfance et l'école. Rev. Pédagogique, Jan., 1898. Vol. 32, pp. 35-41.

26r. Rowe, S. H. Fear in the discipline of the child. The Outlook, Sept. 24, I898. Vol. 60, pp. 232-234.

262. Royce, Josiah The new psychology and the consulting psychologist. Proc. N. E. A., 1898. pp. 554-570.

263. - The psychology of invention. Psychological Review, March, 1898. Vol. 5, pp. II3-I44.

264. Rude, A. Jugendlektüre und Schülerbibliotheken. Rein's Ency. Handb. đ. Pädagogik. Vol. 3, pp. 934-945.

265. Sachse, I. Das Kind und die Zahl. Eine psychologisch-pädagogische Skizze. Zeits. f. Philosophie u. Pädagogik. Langensalza, 1898. Band 5, pp. 356-360.

266. Salge, B. Hysterie bei Kindern. Berlin, 1898 .

267. Sanborn, Alvan F. About boys and boys' clubs. N. A. Review, Aug., 1898. Vol. 167, pp. 254-256.

268. Sanders, W. H. Attitude of Rensselaer pupils toward school. North Western Monthly, Jan., 1898. Vol. 8, pp. 382-385.

269. Schiller, Hermann Der Stundenplan. Ein Kapitel aus der pädagogischen psychologie und physiologie. Samml. von Abh. Geb. a. d. Päd. Psy. u. Physiol. Reuther \& Reichard, 1897. pp. 65.

270. - - Studien und Versuche ueber die Erlernung der Orthographie. Samm1. v. Abh. a. d. Geb. d. Päd. Psy. u. Physiol. Band 2, Heft 4, 1898. pp. 63 .

An excellent experimental study on spelling made in the elementary classes of the Gymnasium at Giessen.

271. Schinz, Albert La moralite de l'enfant. Rev. Philos., March, 1898. Vol, 45, pp. 259-295. Also, translation, by Ch. Ufer, Die Sittlichkeit des Kindes. Beyer u. Söhne, Langensalza, 1898. pp. 42. 
272. Schwalbe, B. Schulhygienische Fragen und Mittheilungen,

H. Heyfelder, Berlin, 1898. pp. 37 .

Presents many measurements of height, weight, etc.

273. Scott, Colin A. Children's fears as material for expression and a basis of education in art. Trans. I11. Soc. for Child Stady, April, 1898. Vol. 3, pp. 12-r7.

274. Seeley, Levi The daily programme in schools. Child Study Monthly, March, r8g8. Vol. 3, pp. 544-549.

Summarizes briefly Friedrich's study on fatigue and Schuyten's study on voluntary attention.

275. Seerley, Homer H. The dangers of the adolescent period. Educational Foundations. E. L. Kellogg \& Co., N. Y., I898.

276. Sheffield, Herman B. A contribution to the study of hysteria in childhood as it occurs in the United States of America. N. Y. Med. Jour., Sept. 17-24, 1898. Vol. 68, pp. 412-416; 433-436.

277. Sheldon, Henry D. The institutional activities of American children. Am. Jour. of Psy, July, 1898. Vol. 9, pp. 425-448.

278. Shinn, Millicent $W$. Comparative importance of the senses in infancy. North Western Monthly, April, r898. Vol. 8, pp. 544-547.

279. Small, M. H. Methods of manifesting the instinct for certainty. Ped. Sem., Jan., 1898. Vol. 5, pp. 313-380.

280. —— An experiment borrowed from the schoolroom. North Western Monthly, Nov., 1898. Vol. 9, pp. 134-I35.

281. Smith, A. T. Psychological tendencies. The study of imitation. Rep. U. S. Comm. of Ed., 1896-97. Vol. I, pp. 671-676.

282. Smith, Nora A. The children of the future. Houghton, Mifflin \& Co., Boston, I898. pp. 165.

Contains chapters on the study of children; training for parenthood; sand and the children; kindergarten training.

283. - The kindergarten made possible in every home, vil lage, or small neighborhood. Ladies' Home Journal, Nov., 1898. Vol, 15, No. 12, p. 20 ; Dec., 1898, Vol. I6, No. I, p. 34 ; Jan., 1899, No. 2, p. 16 ; Feb., I899, No. p. 22.

284. Soldevilla, Carrera, M. La infancia y la criminalidad. Lérida, I897. pp. 240.

285. Solotaroff, $\mathbf{H}$. The origin of the family. Am. Anthropologist, Ang., 1898. Vol. II, pp. 229-242.

286. Stableton, J. K. The study of boys entering the adolescent period. III-IV. The relation of the sexes. V. An untruthful character. VI. The passionate boy. VII. Arrested development. North Western Monthly, Jan., March, April, May, Dec., I898. Vol. 8, pp. 385-386; 484-487; 539-54I ; 589-592. Vol. 9, pp. I38-140; I79-I 80 .

287. Stanley, Hiram M. On the early sense of self. Science, 1898. N. S. Vol. 8, pp. 22-23. (See No. 141.) 
288. Stern, Herman I. The gods of our fathers. Harper \& Brothers, N. Y., I898. pp. 269.

A work on Saxon mythology that every student and teacher should read.

289. Stryker, Mabel F. Children's joys and sorrows. Child Study Monthly, Oct., 1898. Vol. 4, pp. 217-225.

A statistical study of the happiest and saddest days ever experienced by 1,800 school children.

290. Stuart, Ruth McEnery Sonny. A Christmas guest. The Century Co., N. Y., I8g8. pp. 135 .

Should be read by every teacher who has a tendency to magnify his office.

2gr. Sudduth, W. X. Nervous and backward children. Child Study Monthly, March, 1898. Vol. 3, pp. 540-543.

This series of articles continued in the issues for April, May, June and Sept., 1898 .

292. Sutherland, Alexander The origin and growth of the moral instinct. Longmans, Green \& Co., London, 1898. 2 Vols., pp. 46I ; 336.

293. Swift, Edgar James Heredity and environment. A study in adolescence. North Western Monthly, Sept., 1898. Vol. 9, pp. 36-4r. Am. Phys. Ed. Rev., Sept., I8g8. Vol. 3, pp. 170. 178. Proc. N. E. A., 1898. pp. 910-916.

A study of juvenile delinquency.

294. Szentesy, Béla Die geistige Ueberanstrengung des Kindes. I. Theil : Von der Wiege bis zur Mittelschule. II. Theil: Die Psycho.-Physiologie des Musicirens. Pester Buchdruckerei Aktien-Gesellschaft, Budapest, 1898. pp. 123.

Part r. A general characterization of childhood. Part 2. Describes the a thor's theory of playing the piano.

295. Talbot, Eugene S. Degeneracy. Its causes, signs and results. Contemp. Sci. Ser. Charles Scribner's Sons, N. Y., 1898. pp. 372 .

296. - - A study of the stigmata of degeneracy among the American criminal youth. Jour. Am. Med. Ass'n, 1898. Vol. 3o, pp. $849-856$.

297. - Defects of development in childhood. Trans. I11. Soc. for Child Study, Oct. 1898. Vol. 3. pp. 75-90.

298. Taylor, A. R. The study of the child. D. Appleton \& Co., N. Y., 1898. pp. 215.

A brief treatise on the psychology of the child with suggestions for teachers, students, and parents.

299. Taylor, J. L. The amount of work the growing brain should undertake. Bull. Am. Acad. Med., 1898. Vol. 3, pp. 469-482.

300. Taylor, John Madison The nervous mother. Reprint from University Med. Magazine (Phila.), July, 1895. pp. 8.

301. - Puberty in girls and certain of its disturbances. A practical lesson. Reprint from Pediatrics, July 15, 1896. pp. 6. 
302.

Children of feeble resistance : their care and management. Reprint from Int. Med. Mag., Aug., I8g6. pp. 26.

303. Taylor, Joseph $\mathbf{S}$. Some practical aspects of interest. Ped. Sem., April, I8g8. Vol. 5, pp. 497-5 Ir.

304. Thompson, John G. Child study in the training of teachers. North Western Monthly, Sept., 1898. Vol. 9, pp. 41-43. Also Proc. N. E. A., 1898. pp. 916-921.

305. Titchemer, E. B. A primer of psychology. The Macmillan Co., N. Y., 1898, pp. 314 .

306. - - Ebbinghaus's method for the study of fatigue in school hours. Journal of Education, June 30, 1898 . Vol. 48, pp. 7-8.

307. Trüper, Johann Minor mental abnormalities in childhood. Child Study Monthly, May, June, Sept., and Dec., I898. Vol. 4, pp. 2-15;88-97;130-138;342-346.

This is a translation by $C$. C. Van hiew from the German of Truper's exce1lent monograph on Psychopathische Minderwertigkeiten im Kindesalter.

308. — Psychopathisches im Kindesleben. Rein's Ency. Handb. d. Pädagogik. Vol. 5, pp. 588-597.

309. Truslow, Walter Exercise during adolescence. Am. Phys. Ed. Review, June, 1898 . Vol. 3, pp. III-I2I.

310. Tucker, Emmeline F. Nebraska society for child study. North Western Monthly, Jan., 1898. Vol. 8, pp. 387-389.

3rI. - The child and his school reader. North Western Monthly, June, I898. Vol. 8, pp. 654-655.

312. Tümpel, R. Ueber die Versuche geistige Ermüdung durch mechanische Messungen zu untersuchen. Zeits. f. Philos. u. Pädagogik, 1898. Vol. 5, pp. 31-38; r08-II4; 195-I98.

3r3. Ufer, Chr. Zur Beobachtung der Kinder. Die Kinderfehler, Jan., 1898. Vol. 3, pp. I-8.

Presents the claims of child atudy to parents.

354. - - Über Kinderpsychologie. Die Kinderfehler, May, r898. Vol. 3, pp. 65-74.

Vaschide, N. See Binet and Vaschide. (No. 36.)

3I5. Vitali, V. Studi anthropologici in servizio della pedagogia. Vol. r, I Romagnoli. Forli, r896. pp. Ix6. Vol. 2, Le Romagnole. Turin, r898. pp. I30.

Anthropometric and psychological studies of Italian boys and girls.

316. Vivier, H. Sur 1'infantilisme. Jouve, Paris, 1898. pp. $5^{8 .}$

317. Wagner, Ludwig Unterricht und Ermüdung. Ermüdungs. messungen au Schülern des neuen Gymnasiums in Darmstadt. Samml. von Abh. a. d. Geb. d. Paed. Psy. u. Physiol. Vol. I, Heft 4. Reuter u. Reichard, Berlin, 1898. pp. 134.

A study of fatigue in the gymnasium at Darmstadt by means of the com pass asthesiometer. 
318. Weir, James The dawn of reason, or mental traits in the lower animals. Macmillan Co., N. Y., i898. pp. 234.

Takes too high a view of animal mentality.

3rg. Wessely, Rudolf Der Geschmack der Quintaner und Quartaner. Zeits f. d. deuts. Unterricht, 1898. Vol. I2, pp. 449-460.

320. Westermarck, Edward The essence of revenge. Mind, July, r8g8. N. S. Vol. 7, pp. 289-310.

32r. What can child study contribute to the science of education? North Western Monthly, April, 1898. Vol. 8, pp. 535-539.

322. Wilke, G. Die Hauptberührungs Unterscheidungspunkte der Erziehungsgedanken John Locke's und J. J. Rousseau's. Erlangen, 1898 . pp. 65 .

323. Wille, W. Die Psychosen des Pubertätsalters. F. Deuticke, Wien, 1898. pp. 2 r8.

324. Wilson, Louis N. Bibliography of child study. Pedagogical Seminary, April, i898. Vol. 5, pp. 54r-589. The same reprinted in pamphlet form, Clark University Press, Worcester, 1898. pp. 49

A list of 535 books and pamphlets on child study; 13 journals; 16 reports, serial studies, and translations of societies; and $8 \mathrm{I}$ works of standard reference on allied topics. With a subject index.

325. Winship, Albert E. Fitting the curriculum to the different ages of childhood and youth. Journal of Education, Nov. I7, I898. Vol. 48, pp. 320-32r.

A discussion of Pres. G. Stanley Hall's address before the New Eugland Association of School superintendents.

326. Wissler, Clark The interests of children in the reading work of the elementary schools. Ped. Sem., April, I898. Vol. 5, pp. 523-540.

327. —— Pupils' interest as influenced by the teacher. Child Study Monthly, Sept., I898. Vol. 4, pp. 139-146.

A statistical study of the preferences of pupils and teachers for certain school subjects.

328. Wolfe, H. K. Moral training of children. North Western Monthly, Feb., 1898. Vol. 8, pp. 43I-435.

329. Woods, Allce Child study. Jour. of Ed., London, July, 1898 . N. S. Vol. 20, pp. 396-397.

330. Yoder, A. H. Pubescence. North Western Monthly, May, I898. Vol. 8, pp. 597-600.

33I. Ziehen, Th. Die Ideenassoziation des Kindes. Erste Abhandlung. Abh. a, d. Geb. d. Paed. Psy. u. Physiol. Band r, Heft 6 . Reuter \& Reichard, Berlin, 1898. pp. 66.

A study of the association of ideas of boys from 8 to 44 years.

332. - - Nervensystem. Rein's Ency. Handb. d. Pädagogik. Vol. 5, pp. 89-92.

333. Zueblin, Charles Municipal playgrounds in Chicago. Am. Jour. of Sociology, Sept., 1898 . Vol. 4, pp. r45-158. 